\begin{tabular}{|c|c|c|c|c|c|c|}
\hline \multirow{4}{*}{ Impact Factor: } & ISRA (India) & $=3.117$ & SIS (USA) & $=0.912$ & ICV (Poland) & $=6.630$ \\
\hline & ISI (Dubai, UAE & $=0.829$ & РИНЦ (Russia & $=\mathbf{0 . 1 5 6}$ & PIF (India) & $=1.940$ \\
\hline & GIF (Australia) & $=0.564$ & ESJI (KZ) & $=8.716$ & IBI (India) & $=4.260$ \\
\hline & JIF & $=1.500$ & SJIF (Morocco & $=\mathbf{5 . 6 6 7}$ & OAJI (USA) & $=0.350$ \\
\hline
\end{tabular}

\begin{tabular}{|c|c|}
\hline $\begin{array}{l}\text { SOI: } 1.1 / \mathrm{TA} \\
\text { International Sc } \\
\text { Theoretical \& A }\end{array}$ & $\begin{array}{l}S \text { DOI: } 10.15863 / T A S \\
\text { ientific Journal } \\
\text { pplied Science }\end{array}$ \\
\hline p-ISSN: 2308-4944 (print) & e-ISSN: 2409-0085 (online) \\
\hline Year: 2019 & Volume: 72 \\
\hline Published: 24.04 .2019 & http://T-Science.org \\
\hline
\end{tabular}

SECTION 7. Mechanics and machine construction.
QR - Issue

QR - Article
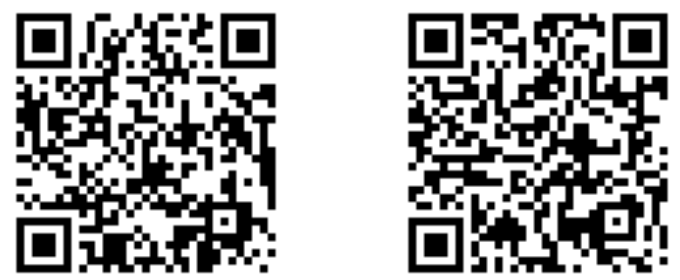

Denis Chemezov

M.Sc.Eng., Corresponding Member of International Academy of Theoretical and Applied Sciences, Lecturer of Vladimir Industrial College, Russian Federation https://orcid.org/0000-0002-2747-552X chemezov-da@yandex.ru

Alexandra Strunina Lecturer of Vladimir Industrial College, Russian Federation

Evgeny Knyazkov Student of Vladimir Industrial College, Russian Federation

Maxim Zatsepilov Student of Vladimir Industrial College, Russian Federation

Evgeny Vakhromeev Student of Vladimir Industrial College, Russian Federation

Galina Zhivoglyadova Master of Industrial Training, Vladimir Industrial College, Russian Federation

Elena Kiseleva Master of Industrial Training, Vladimir Industrial College, Russian Federation

Elena Lezova Master of Industrial Training, Vladimir Industrial College, Russian Federation

\title{
DISPLACEMENTS GRADIENTS OF CANTILEVER AND DOUBLY SUPPORTED STEEL I-BEAMS AT BENDING
}

Abstract: Isosurfaces of displacements gradients of cantilever and doubly supported steel I-beams loaded with concentrated and distributed forces were obtained by a computer simulation. Displacement gradient of the beams material (nine components) is presented by the deformation coefficient. The most uniform displacement of the Ibeams material was determined along the $x \mathrm{Z}$ plane.

Key words: an I-beam, gradient, a component, force, moment, a coefficient.

Language: English

Citation: Chemezov, D., et al. (2019). Displacements gradients of cantilever and doubly supported steel I-beams at bending. ISJ Theoretical \& Applied Science, 04 (72), 301-312.

Soi: http://s-o-i.org/1.1/TAS-04-72-34 Doi: crossef https://dx.doi.org/10.15863/TAS.2019.04.72.34 


\begin{tabular}{|c|c|c|c|c|c|c|}
\hline \multirow{4}{*}{ Impact Factor: } & ISRA (India) & $=3.117$ & SIS (USA) & $=0.912$ & ICV (Poland) & $=6.630$ \\
\hline & ISI (Dubai, UAE & $=0.829$ & РИНЦ (Russia & $=0.156$ & PIF (India) & $=1.940$ \\
\hline & GIF (Australia) & $=0.564$ & ESJI (KZ) & $=8.716$ & IBI (India) & $=4.260$ \\
\hline & JIF & $=1.500$ & SJIF (Morocco & $=5.667$ & OAJI (USA) & $=0.350$ \\
\hline
\end{tabular}

\section{Introduction}

Variable bending moment and constant shear force occur in a cross section of loaded cantilever single supported beams. Bending moment is resultant of elementary moments arising as a result of the action of longitudinal elastic forces. Shear force is resultant of tangential forces of elasticity. Arising shear stresses prevent shear of material layers in the loaded doubly supported beam. Shear stresses are zero on a surface.

The beams must have sufficiently rigidity. The longitudinal axis of the beam is bent at the action of shear forces. Each cross section has vertical and horizontal displacement as the result of the beam deformation. The researches of elastoplastic deformations of the I-beams were carried out in the works [1 - 7].

The computer simulation was used in this article for determining of the cross sections displacement of the I-beam throughout the volume at bending.

\section{Materials and methods}

The steel I-beams were subjected to bending. Four I-beams were fixed on one support; five I-beams were fixed on two supports. Concentrated or distributed forces and concentrated moment were applied on the I-beams. These loads acted on different parts of the I-beams span.

The full information about the methods of the computer research of stress-strain state of the I-beams material is presented in the works [8-10].

\section{Results and discussion}

The layers displacement of the I-beams material at bending is presented by gradient. The color contours (the isosurfaces) of gradient show a displacement direction of the material layers of the deformed I-beam.

The isosurfaces of displacement gradient of the cantilever and doubly supported steel I-beams at bending are presented in the Fig. $1-9$.

The first four cantilever beams have the displacement direction of the material layers from the support. Maximum intensity of the layers displacement of material occurs at the action of distributed force on the upper flange of the I-beam. Displacement gradient is expressed by the deformation coefficient. Displacement gradient has the minimum values at the action of concentrated moment.

The changes of displacement gradient of the material layers of the I-beam along the main coordinate axes were considered in the polar coordinate system. The graphs are presented for the second loading scheme of the I-beam, since maximum deformation of material occurs in it.

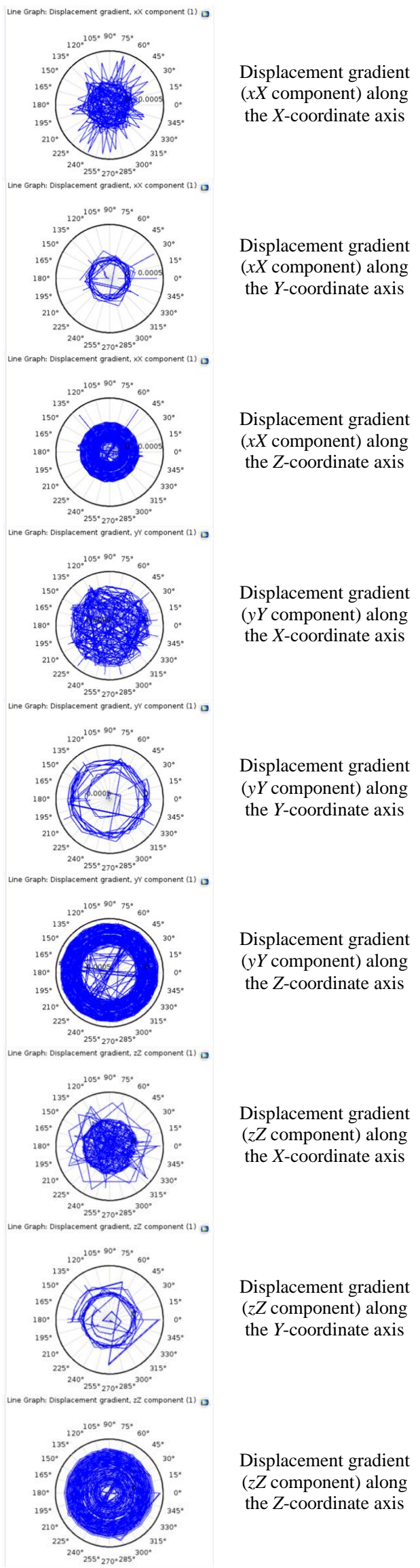




\begin{tabular}{|c|c|c|c|c|c|c|}
\hline \multirow{4}{*}{ Impact Factor: } & ISRA (India) & $=3.117$ & SIS (USA) & $=0.912$ & ICV (Poland) & $=6.630$ \\
\hline & ISI (Dubai, UAE & $=0.829$ & РИНЦ (Russia & $=0.156$ & PIF (India) & $=1.940$ \\
\hline & GIF (Australia) & $=0.564$ & ESJI (KZ) & $=8.716$ & IBI (India) & $=4.260$ \\
\hline & JIF & $=1.500$ & SJIF (Morocce & $=5.667$ & OAJI (USA) & $=0.350$ \\
\hline
\end{tabular}

$\boldsymbol{A}$

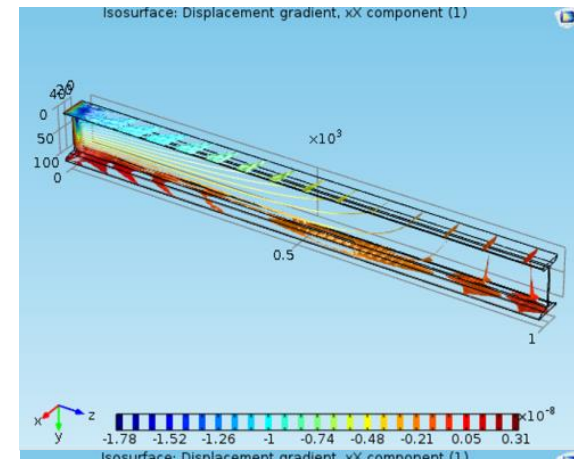

$C$

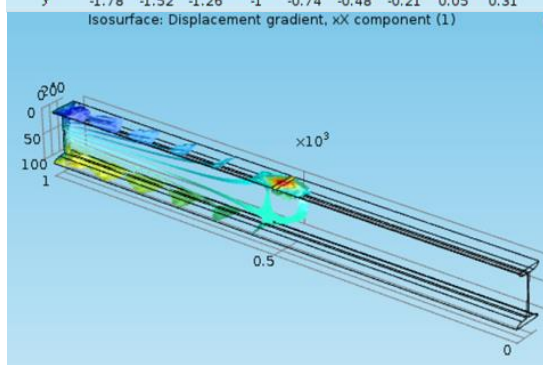

$\boldsymbol{E}$

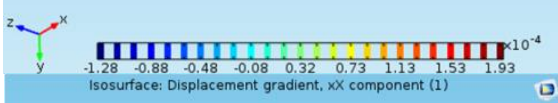

$\boldsymbol{G}$

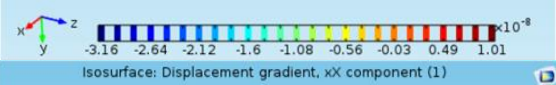

I
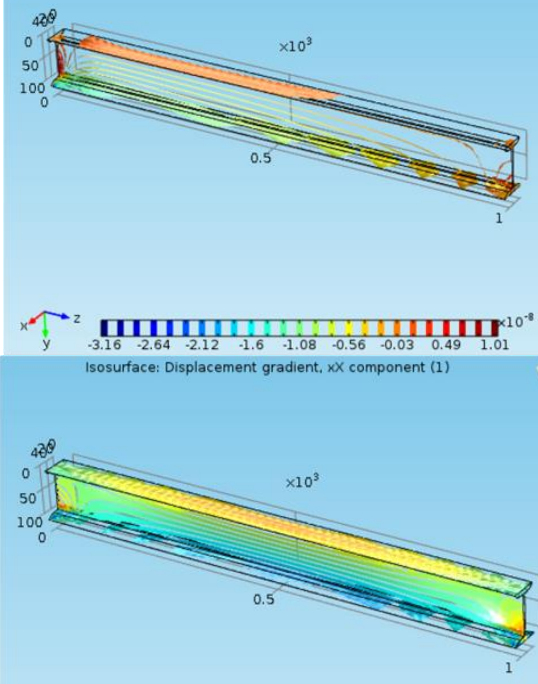

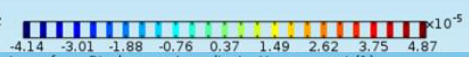

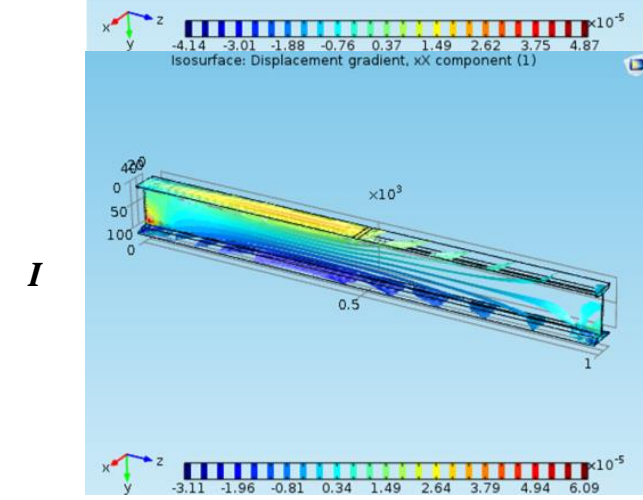

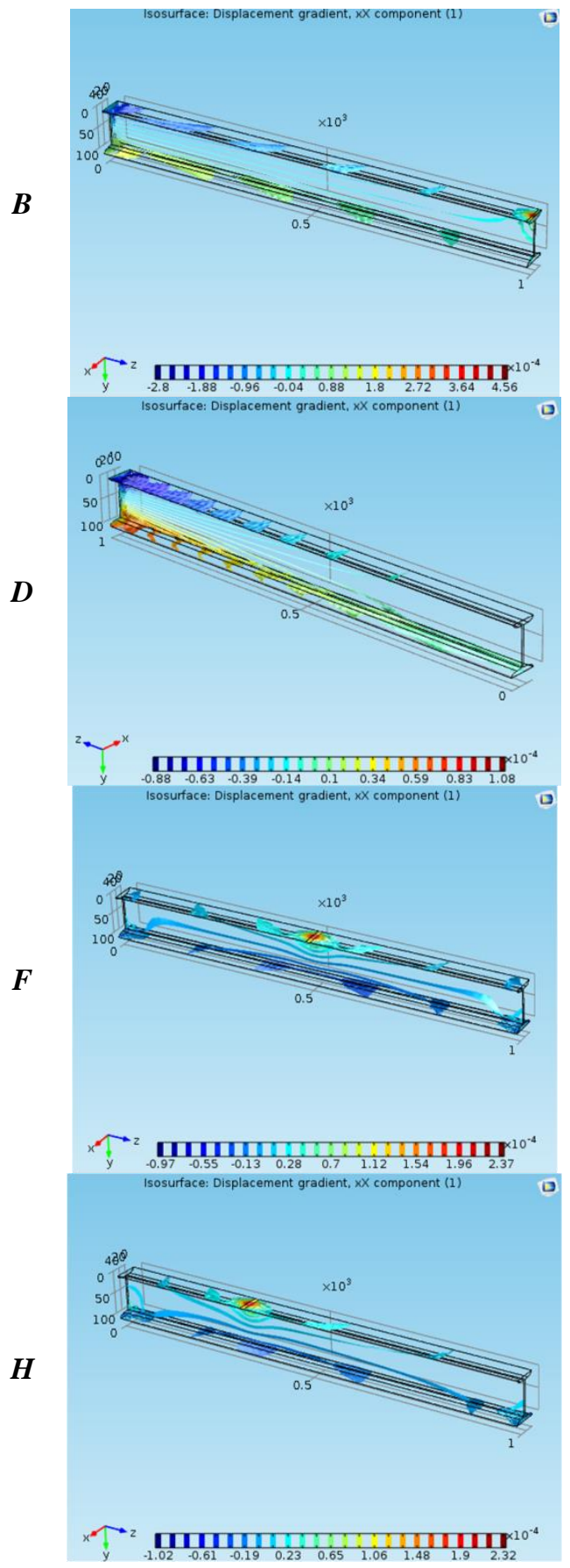

Figure 1 - Displacement gradient, $\boldsymbol{X X}$ component: $\boldsymbol{A}$ - the first scheme; $\boldsymbol{B}$ - the second scheme; $\boldsymbol{C}$ - the third scheme; $D$ - the fourth scheme; $E$ - the fifth scheme; $F$ - the sixth scheme; $G$ - the seventh scheme; $H$ - the eighth scheme; $I$ - the ninth scheme. 


\begin{tabular}{|c|c|c|c|c|c|c|}
\hline \multirow{4}{*}{ Impact Factor: } & ISRA (India) & $=3.117$ & SIS (USA) & $=0.912$ & ICV (Poland) & $=6.630$ \\
\hline & ISI (Dubai, UAE & $=0.829$ & РИНЦ (Russia & $=0.156$ & PIF (India) & $=1.940$ \\
\hline & GIF (Australia) & $=0.564$ & ESJI (KZ) & $=8.716$ & IBI (India) & $=4.260$ \\
\hline & JIF & $=1.500$ & SJIF (Morocce & $=5.667$ & OAJI (USA) & $=0.350$ \\
\hline
\end{tabular}

$\boldsymbol{A}$

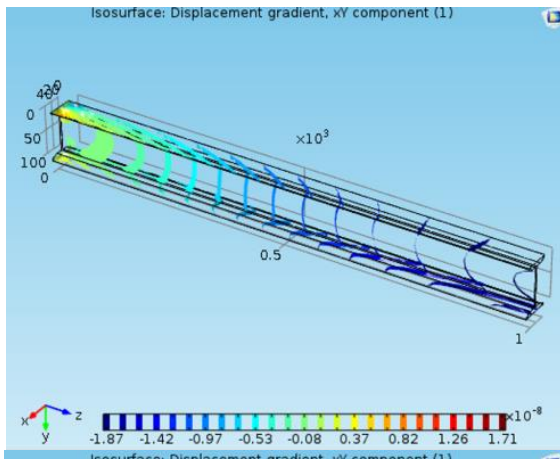

$C$

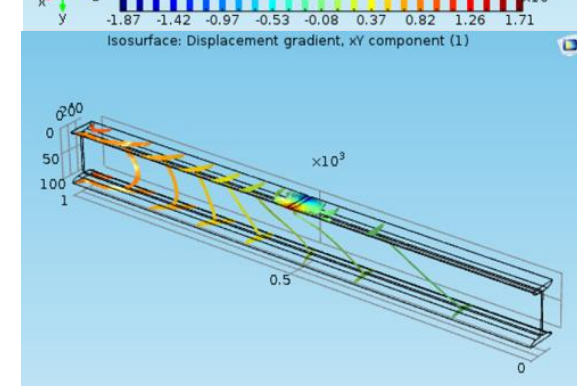

$\boldsymbol{E}$

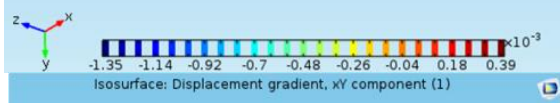

$\boldsymbol{G}$
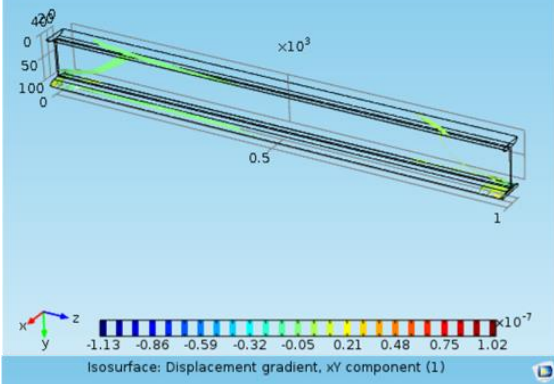

I

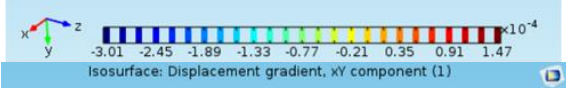

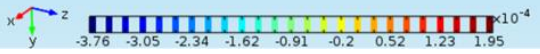

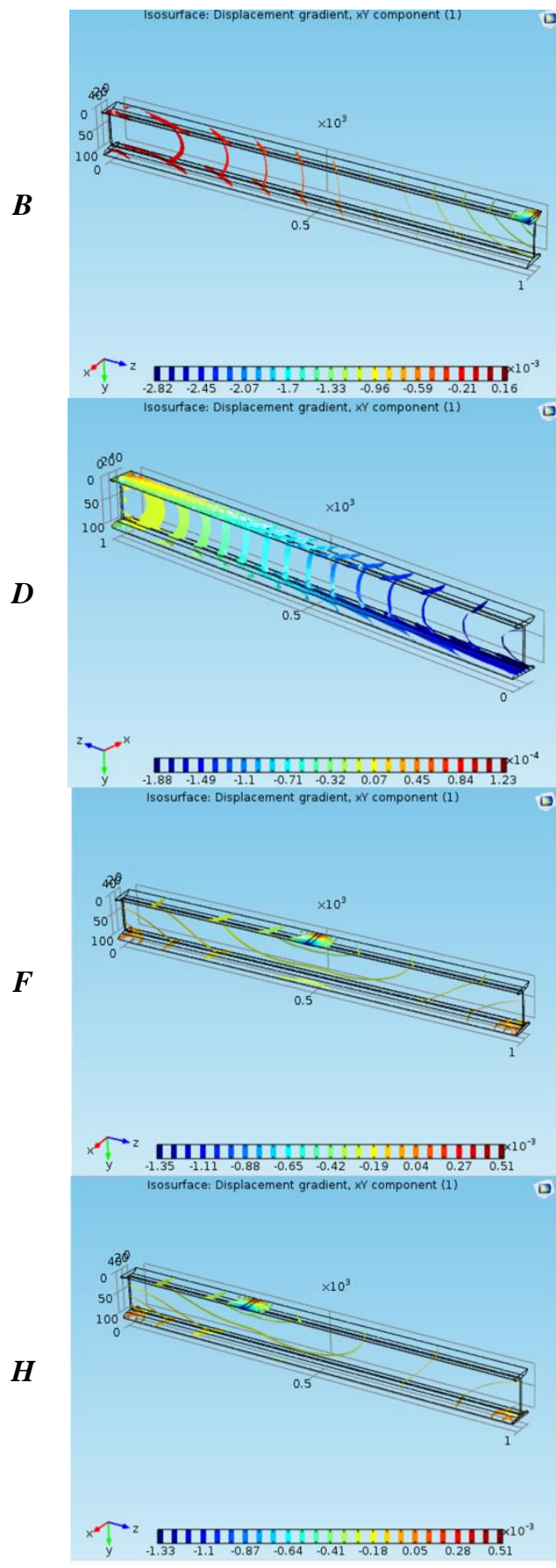

Figure 2 - Displacement gradient, $x Y$ component: $A$ - the first scheme; $B$ - the second scheme; $C$ - the third scheme; $D$ - the fourth scheme; $E$ - the fifth scheme; $F$ - the sixth scheme; $G$ - the seventh scheme; $H$ - the eighth scheme; $I$ - the ninth scheme. 


\begin{tabular}{|c|c|c|c|c|c|c|}
\hline \multirow{4}{*}{ Impact Factor: } & ISRA (India) & $=3.117$ & SIS (USA) & $=0.912$ & ICV (Poland) & $=6.630$ \\
\hline & ISI (Dubai, UAE & $=0.829$ & РИНЦ (Russia & $=0.156$ & PIF (India) & $=1.940$ \\
\hline & GIF (Australia) & $=0.564$ & ESJI (KZ) & $=8.716$ & IBI (India) & $=4.260$ \\
\hline & JIF & $=1.500$ & SJIF (Morocce & $=5.667$ & OAJI (USA) & $=0.350$ \\
\hline
\end{tabular}

$\boldsymbol{A}$

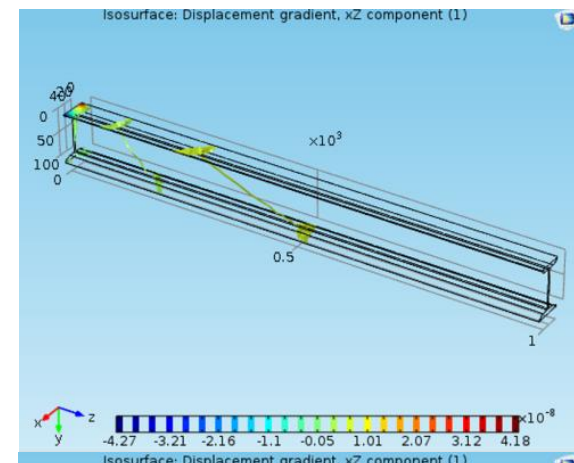

$C$

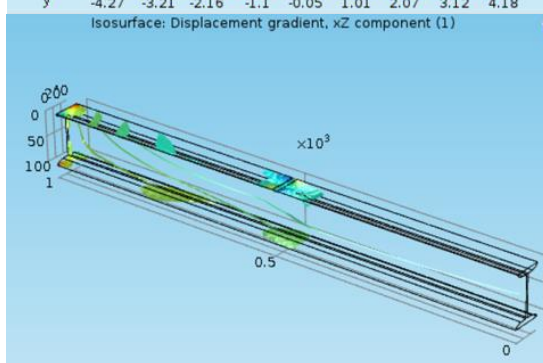

$\boldsymbol{E}$

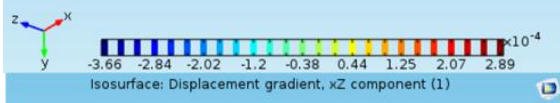

$\boldsymbol{G}$
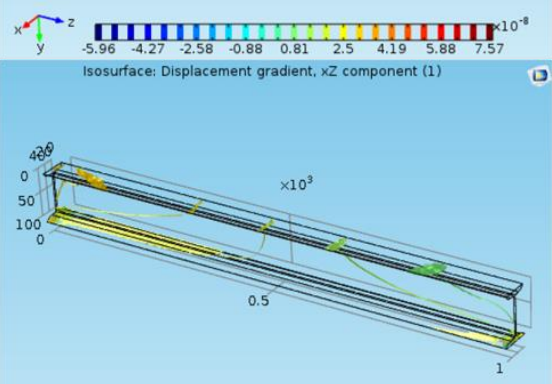

I
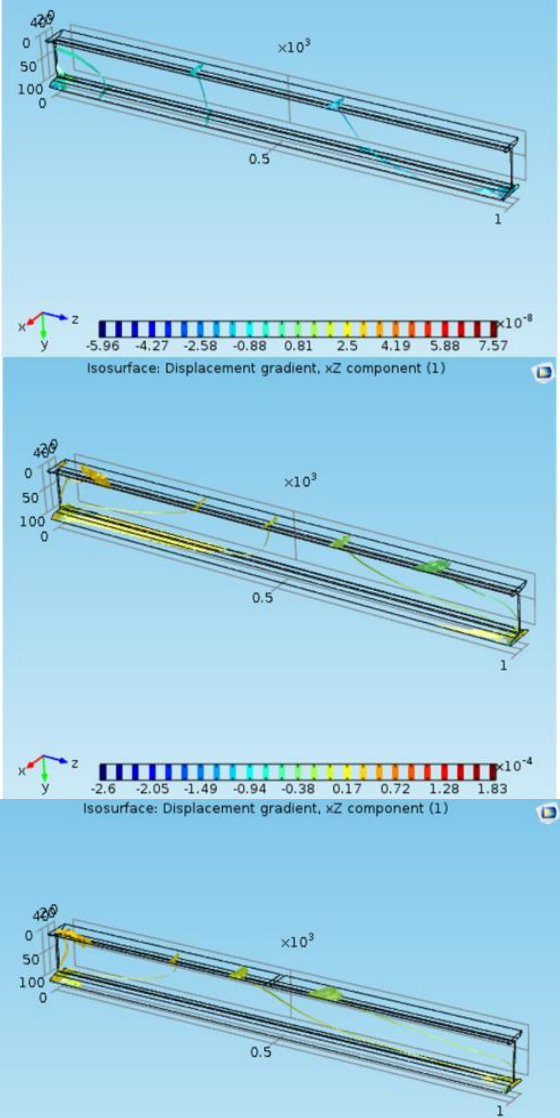

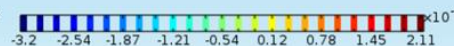

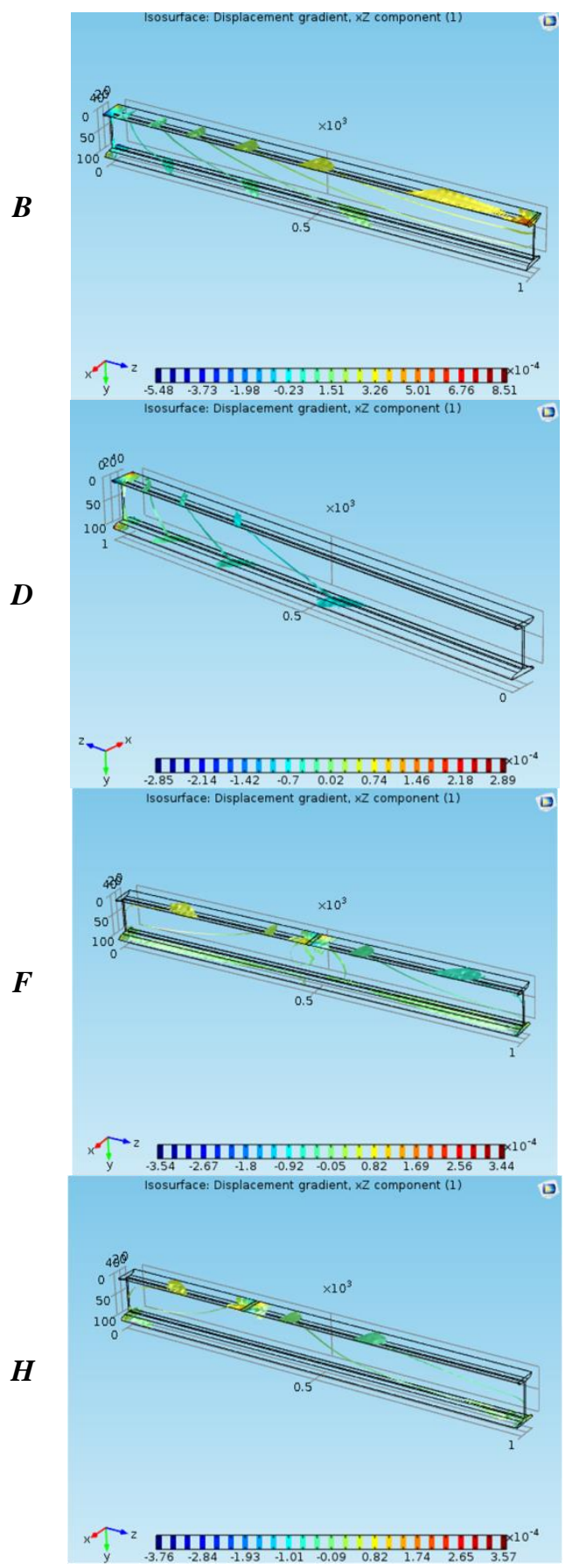

Figure 3 - Displacement gradient, $x Z$ component: $A$ - the first scheme; $B$ - the second scheme; $C$ - the third scheme; $D$ - the fourth scheme; $E$ - the fifth scheme; $F$ - the sixth scheme; $G$ - the seventh scheme; $H$ - the eighth scheme; $I$ - the ninth scheme. 


\begin{tabular}{|c|c|c|c|c|c|c|}
\hline \multirow{4}{*}{ Impact Factor: } & ISRA (India) & $=3.117$ & SIS (USA) & $=0.912$ & ICV (Poland) & $=6.630$ \\
\hline & ISI (Dubai, UAE & $=0.829$ & РИНЦ (Russia & $=0.156$ & PIF (India) & $=1.940$ \\
\hline & GIF (Australia) & $=0.564$ & ESJI (KZ) & $=8.716$ & IBI (India) & $=4.260$ \\
\hline & JIF & $=1.500$ & SJIF (Morocce & $=5.667$ & OAJI (USA) & $=0.350$ \\
\hline
\end{tabular}

$\boldsymbol{A}$

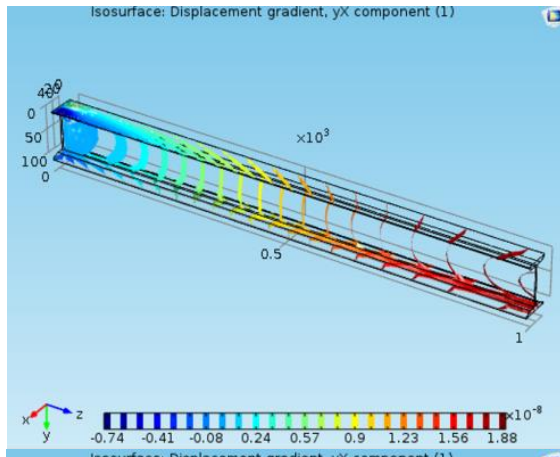

$C$

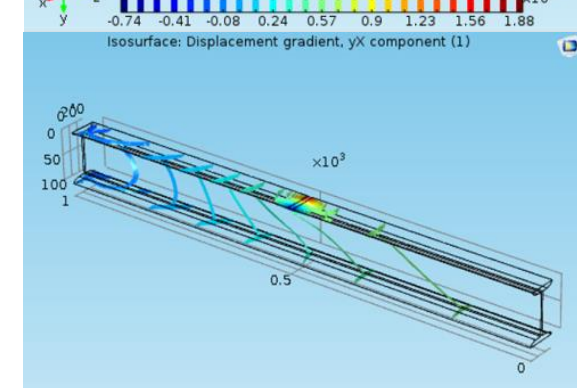

$\boldsymbol{E}$

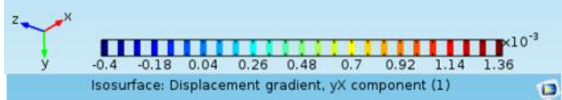

G
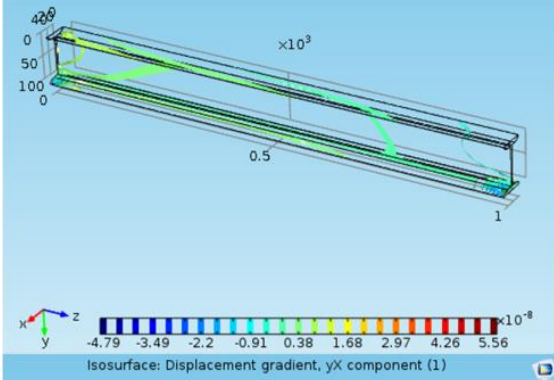

I

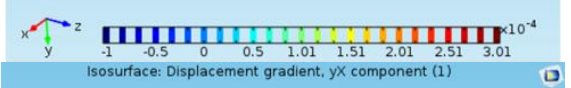

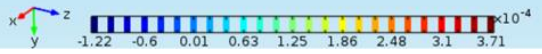

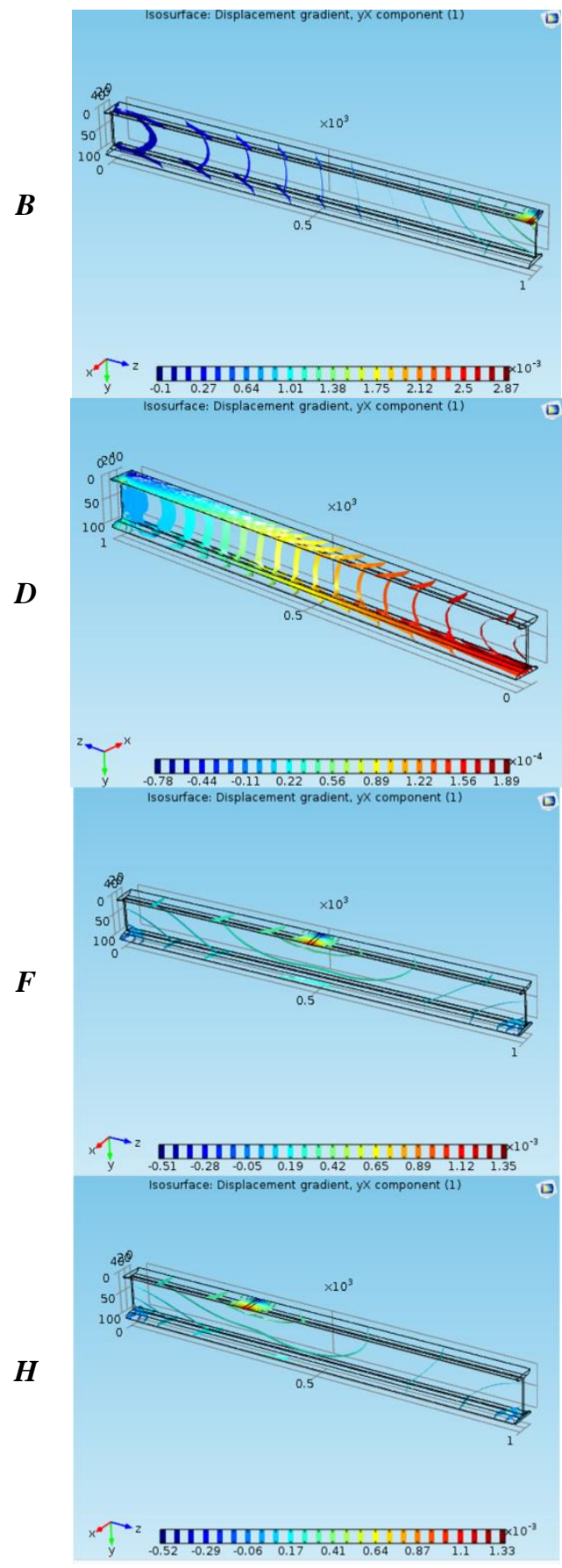

Figure 4 - Displacement gradient, $y X$ component: $A$ - the first scheme; $B$ - the second scheme; $C$ - the third scheme; $D$ - the fourth scheme; $E$ - the fifth scheme; $F$ - the sixth scheme; $G$ - the seventh scheme; $H$ - the eighth scheme; $I$ - the ninth scheme. 


\begin{tabular}{|c|c|c|c|c|c|c|}
\hline \multirow{4}{*}{ Impact Factor: } & ISRA (India) & $=3.117$ & SIS (USA) & $=0.912$ & ICV (Poland) & $=6.630$ \\
\hline & ISI (Dubai, UAE & $=0.829$ & РИНЦ (Russia & $=0.156$ & PIF (India) & $=1.940$ \\
\hline & GIF (Australia) & $=0.564$ & ESJI (KZ) & $=8.716$ & IBI (India) & $=4.260$ \\
\hline & JIF & $=1.500$ & SJIF (Morocce & $=5.667$ & OAJI (USA) & $=0.350$ \\
\hline
\end{tabular}

$A$

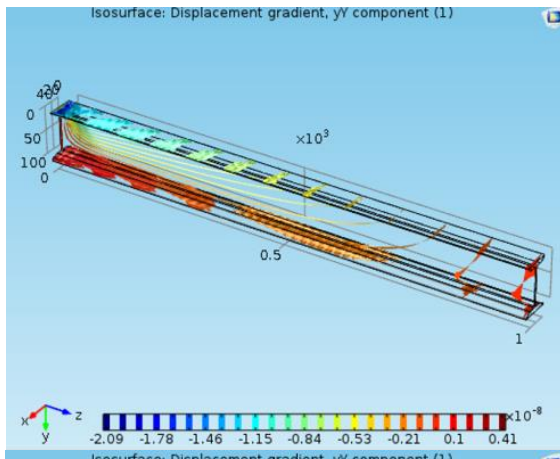

$C$

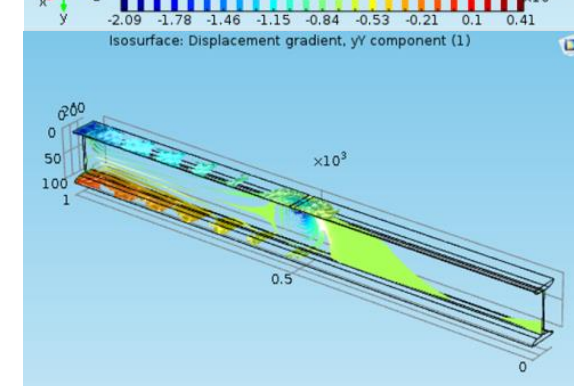

$\boldsymbol{E}$

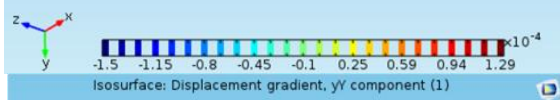

$\boldsymbol{G}$
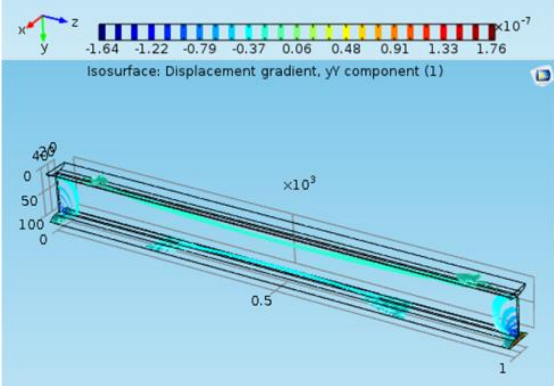

I

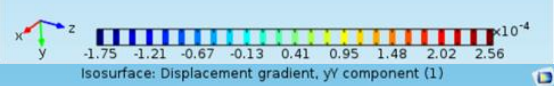

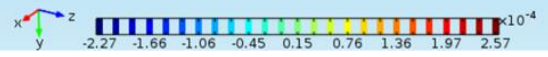

Figure 5 - Displacement gradient, $y Y$ component: $A$ - the first scheme; $B$ - the second scheme; $C$ - the third scheme; $D$ - the fourth scheme; $E$ - the fifth scheme; $F$ - the sixth scheme; $G$ - the seventh scheme; $H$ - the eighth scheme; $I$ - the ninth scheme.
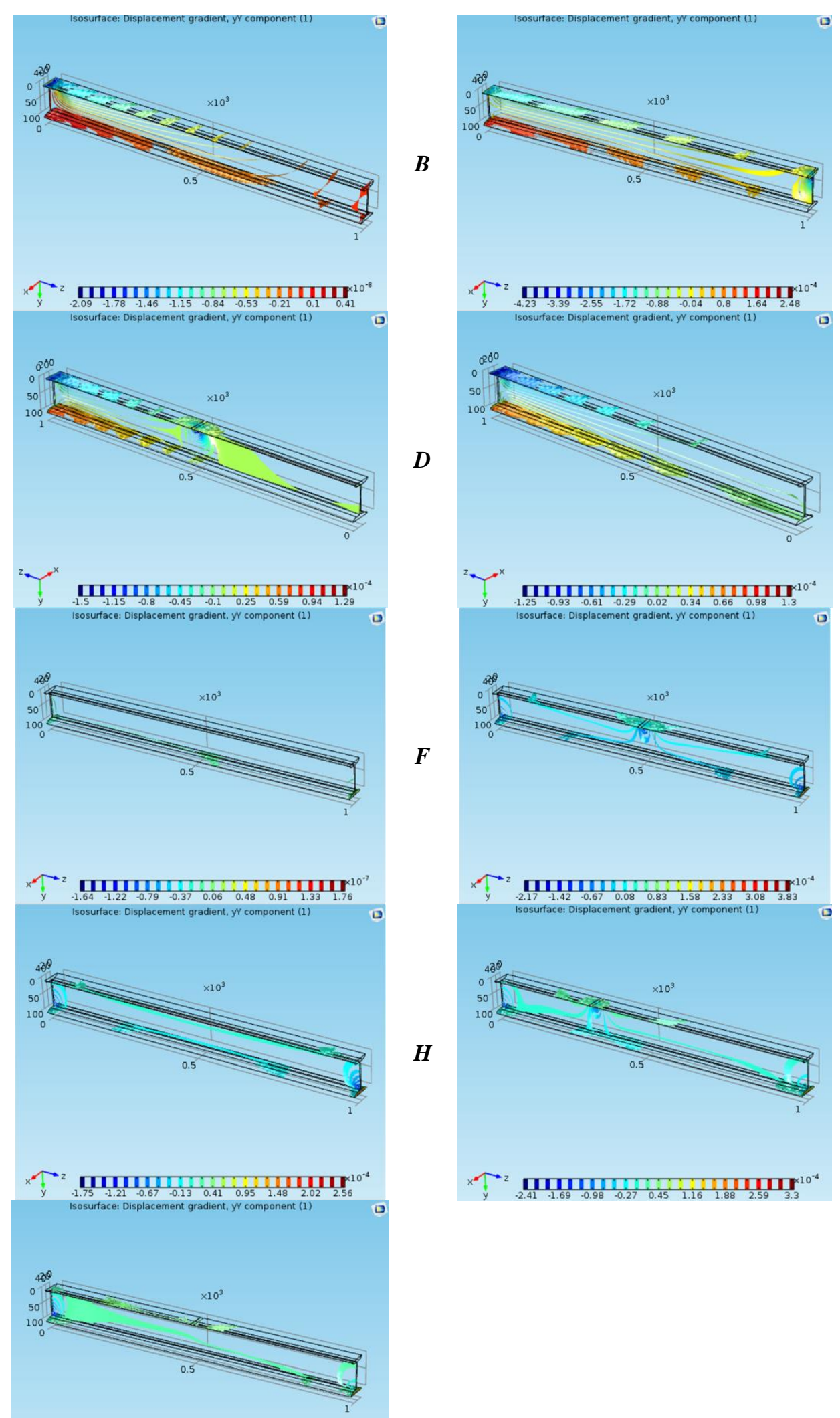


\begin{tabular}{|c|c|c|c|c|c|c|}
\hline \multirow{4}{*}{ Impact Factor: } & ISRA (India) & $=3.117$ & SIS (USA) & $=0.912$ & ICV (Poland) & $=6.630$ \\
\hline & ISI (Dubai, UAE & $=0.829$ & РИНЦ (Russia & $=0.156$ & PIF (India) & $=1.940$ \\
\hline & GIF (Australia) & $=0.564$ & ESJI (KZ) & $=8.716$ & IBI (India) & $=4.260$ \\
\hline & JIF & $=1.500$ & SJIF (Morocco & $=5.667$ & OAJI (USA) & $=0.350$ \\
\hline
\end{tabular}

$\boldsymbol{A}$
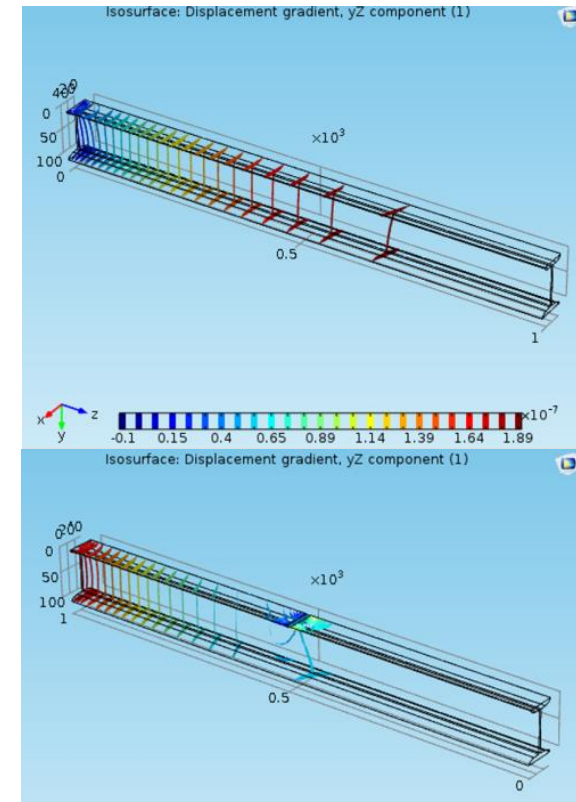

$\boldsymbol{E}$

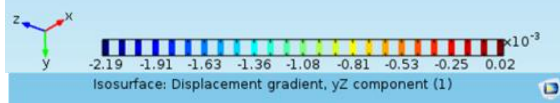

$\boldsymbol{G}$
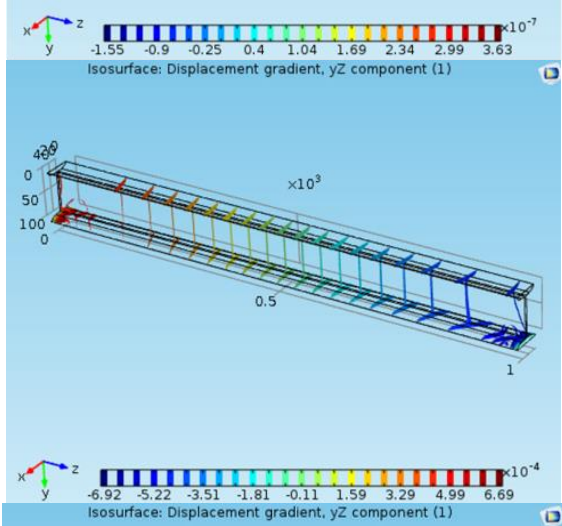

$\boldsymbol{I}$
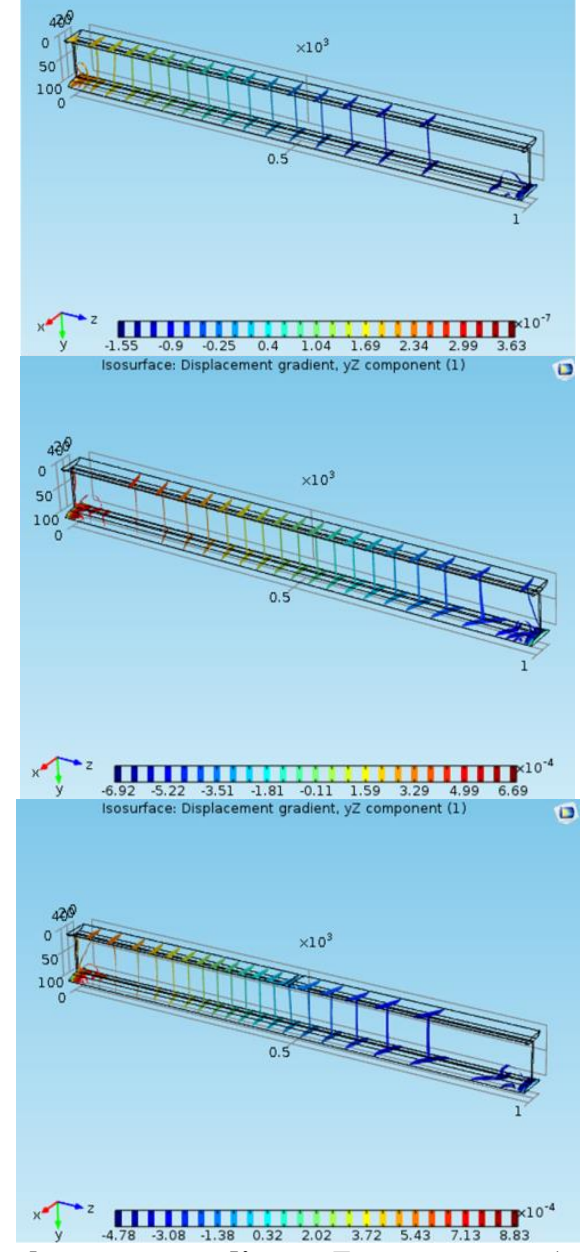

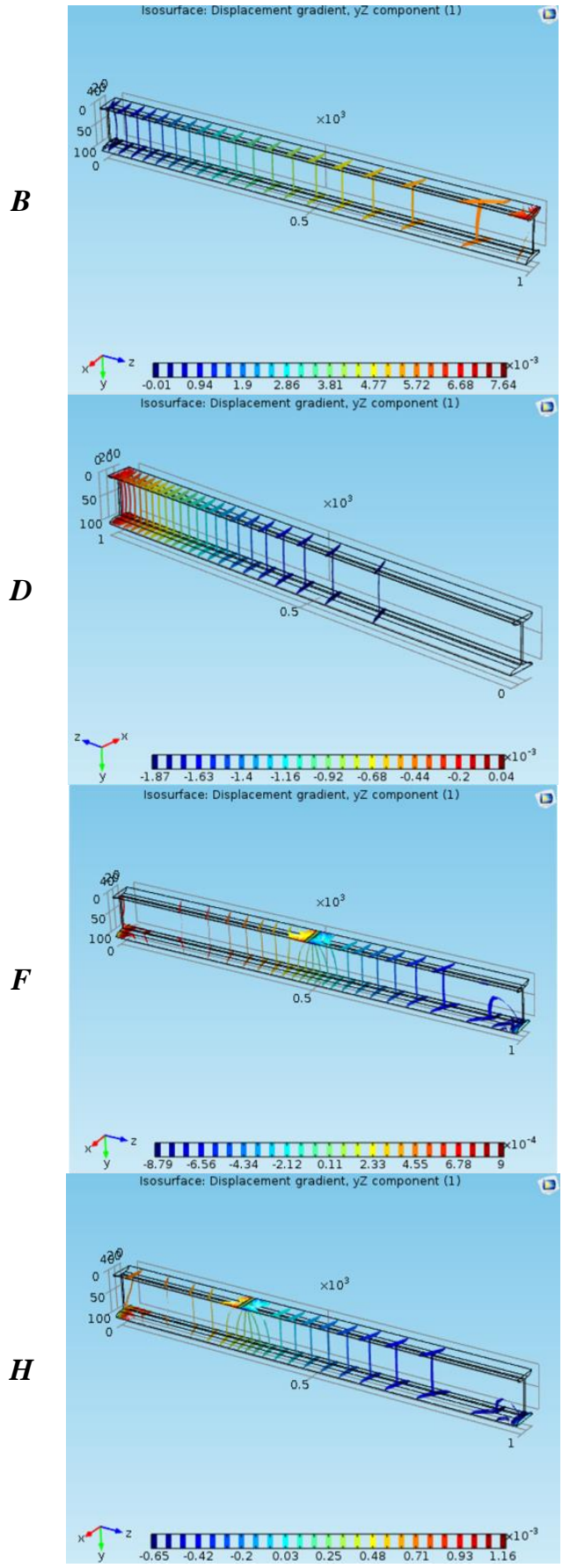

Figure 6 - Displacement gradient, $y Z$ component: $A$ - the first scheme; $B$ - the second scheme; $C$ - the third scheme; $D$ - the fourth scheme; $E$ - the fifth scheme; $F$ - the sixth scheme; $G$ - the seventh scheme; $H$ - the eighth scheme; $I$ - the ninth scheme. 


\begin{tabular}{|c|c|c|c|c|c|c|}
\hline \multirow{4}{*}{ Impact Factor: } & ISRA (India) & $=3.117$ & SIS (USA) & $=0.912$ & ICV (Poland) & $=6.630$ \\
\hline & ISI (Dubai, UAE & $=0.829$ & РИНЦ (Russia & $=0.156$ & PIF (India) & $=1.940$ \\
\hline & GIF (Australia) & $=0.564$ & ESJI (KZ) & $=8.716$ & IBI (India) & $=4.260$ \\
\hline & JIF & $=1.500$ & SJIF (Morocco & $=5.667$ & OAJI (USA) & $=0.350$ \\
\hline
\end{tabular}

$\boldsymbol{A}$

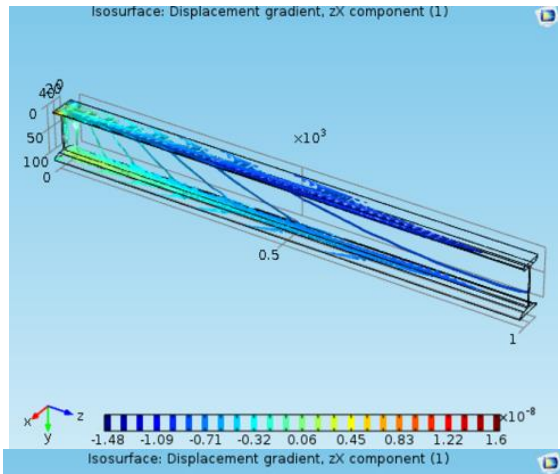

$C$
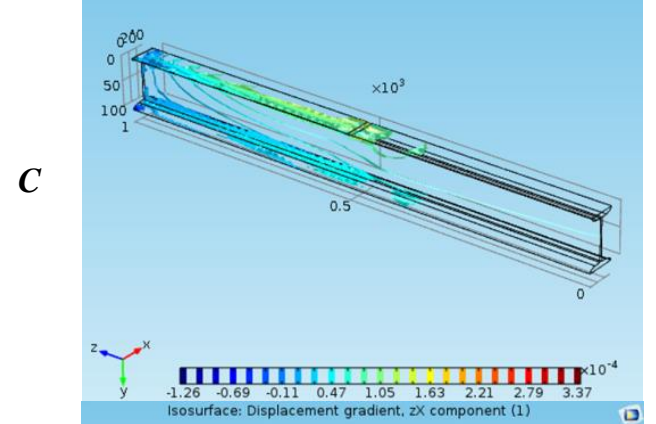

$\boldsymbol{E}$

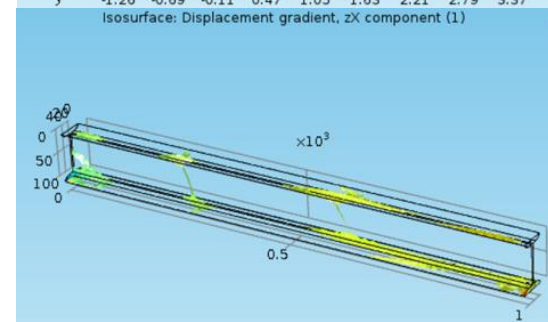

$\boldsymbol{G}$
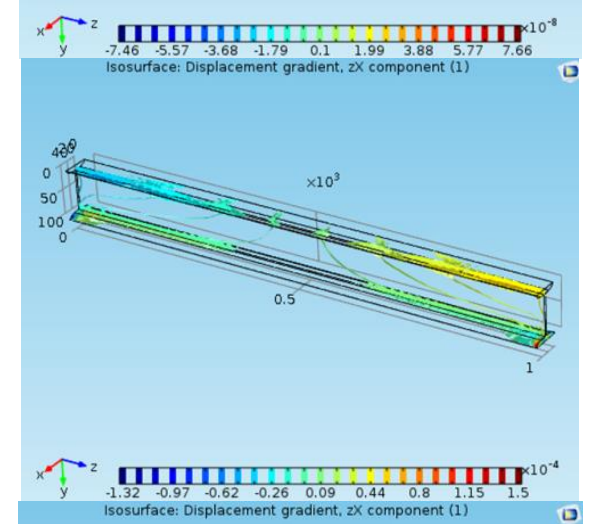

$\boldsymbol{I}$

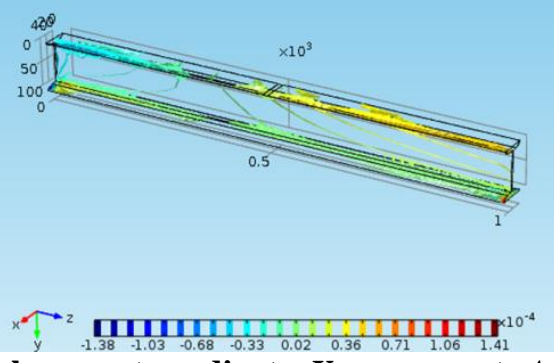

$\boldsymbol{B}$

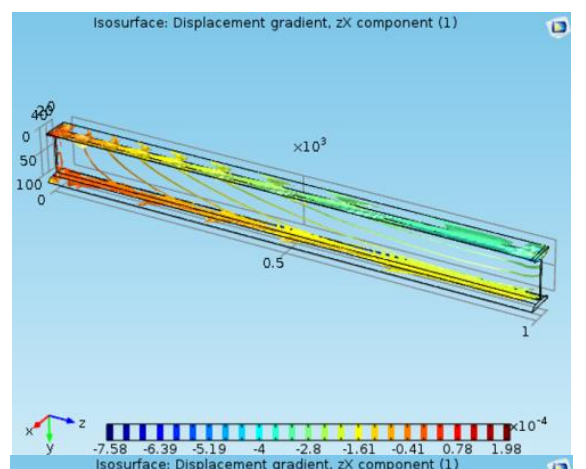

$D$

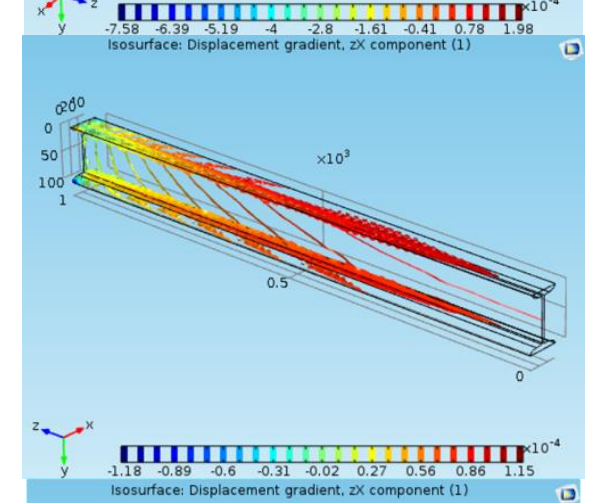

$\boldsymbol{F}$

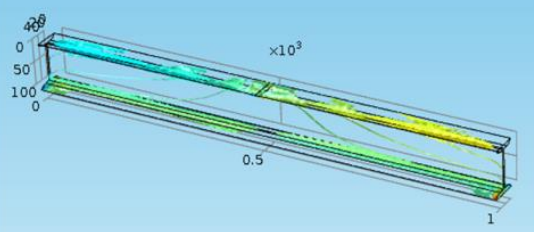

$\boldsymbol{H}$
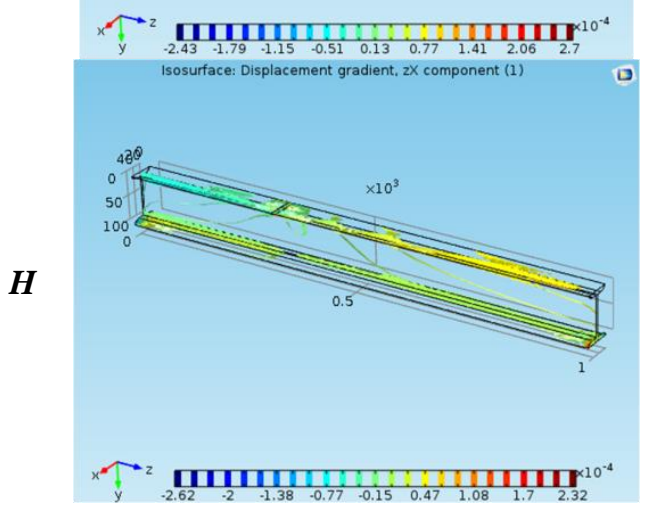

Figure 7 - Displacement gradient, $z X$ component: $A$ - the first scheme; $B$ - the second scheme; $C$ - the third scheme; $D$ - the fourth scheme; $E$ - the fifth scheme; $F$ - the sixth scheme; $G$ - the seventh scheme; $H$ - the eighth scheme; $I$ - the ninth scheme. 


\begin{tabular}{|c|c|c|c|c|c|c|}
\hline \multirow{4}{*}{ Impact Factor: } & ISRA (India) & $=3.117$ & SIS (USA) & $=0.912$ & ICV (Poland) & $=6.630$ \\
\hline & ISI (Dubai, UAE & $=0.829$ & РИНЦ (Russia & $=0.156$ & PIF (India) & $=1.940$ \\
\hline & GIF (Australia) & $=0.564$ & ESJI (KZ) & $=8.716$ & IBI (India) & $=4.260$ \\
\hline & JIF & $=1.500$ & SJIF (Morocco & $=5.667$ & OAJI (USA) & $=0.350$ \\
\hline
\end{tabular}

$\boldsymbol{A}$

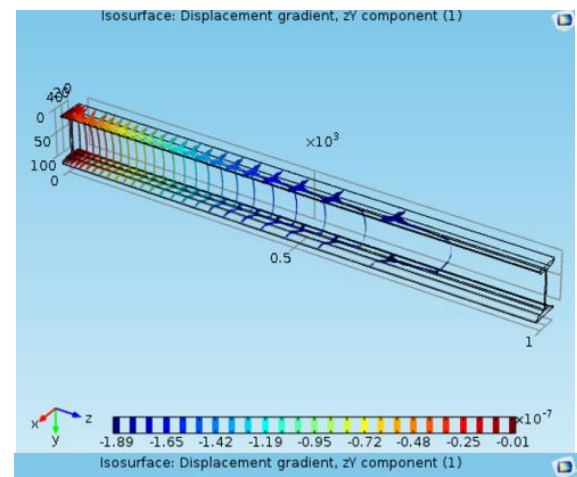

$C$
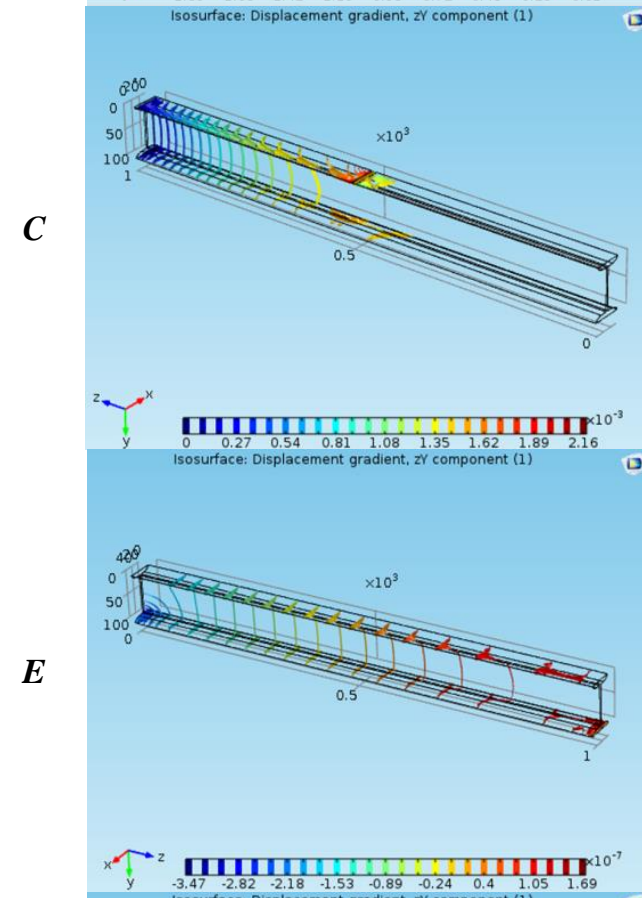

$G$

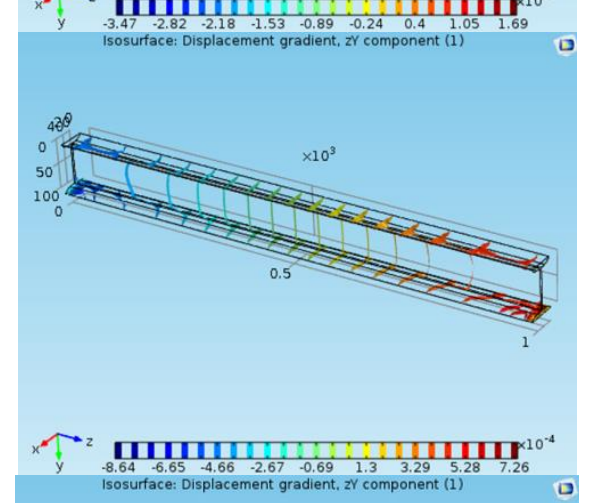

I

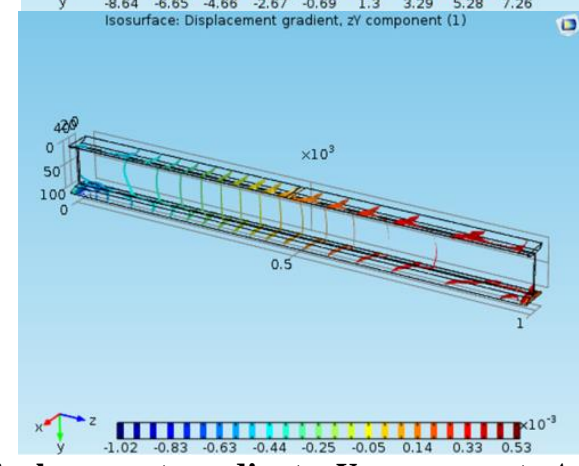

$\boldsymbol{B}$

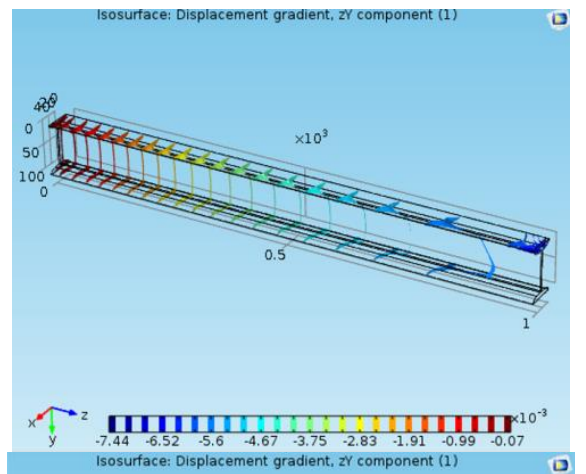

$D$

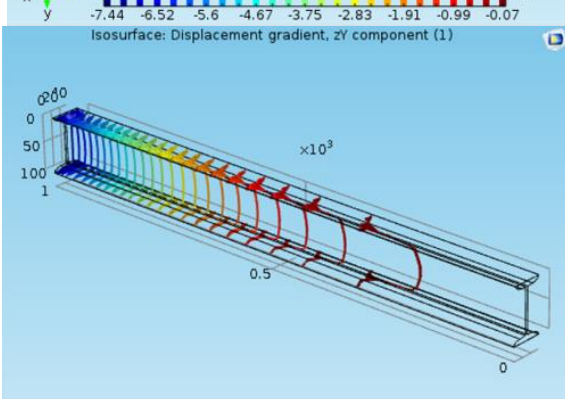

$\boldsymbol{F}$

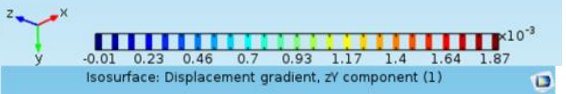

$H$

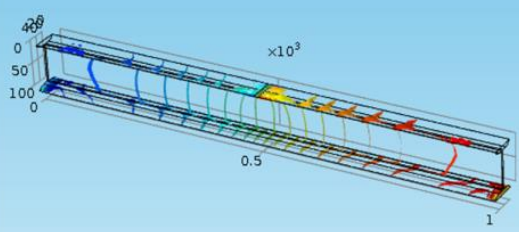

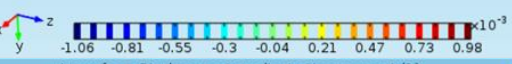
sosurface: Displacement gradient, zY component (1)

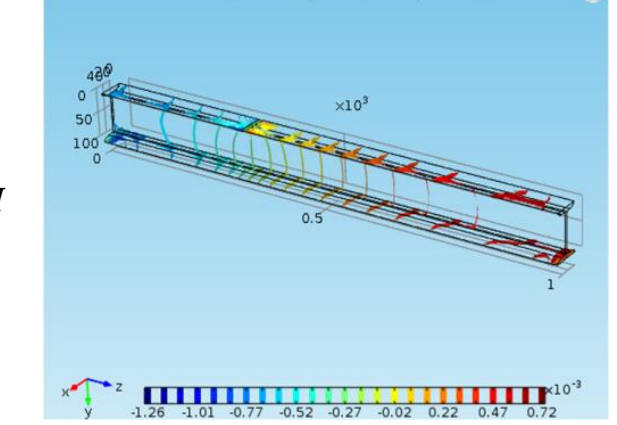

Figure 8 - Displacement gradient, $z \boldsymbol{Y}$ component: $\boldsymbol{A}$ - the first scheme; $B$ - the second scheme; $\boldsymbol{C}$ - the third scheme; $D$ - the fourth scheme; $E$ - the fifth scheme; $F$ - the sixth scheme; $G$ - the seventh scheme; $H$ - the eighth scheme; $I$ - the ninth scheme. 


\begin{tabular}{|c|c|c|c|c|c|c|}
\hline \multirow{4}{*}{ Impact Factor: } & ISRA (India) & $=3.117$ & SIS (USA) & $=0.912$ & ICV (Poland) & $=6.630$ \\
\hline & ISI (Dubai, UAE & $=0.829$ & РИНЦ (Russia) & $=0.156$ & PIF (India) & $=1.940$ \\
\hline & GIF (Australia) & $=0.564$ & ESJI (KZ) & $=8.716$ & IBI (India) & $=4.260$ \\
\hline & JIF & $=1.500$ & SJIF (Morocco) & $=5.667$ & OAJI (USA) & $=0.350$ \\
\hline
\end{tabular}

$\boldsymbol{A}$

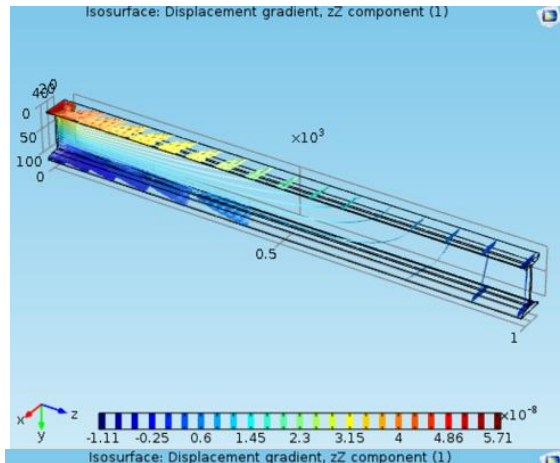

$C$

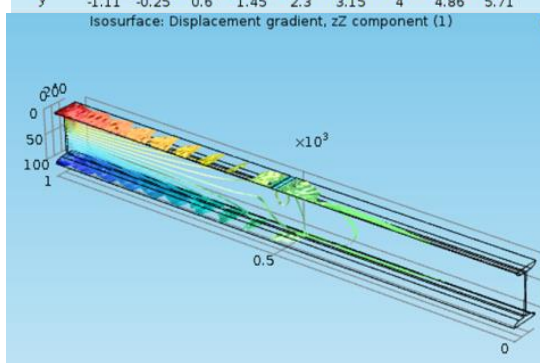

$\boldsymbol{E}$

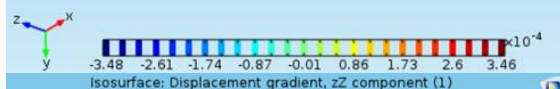

$\boldsymbol{G}$
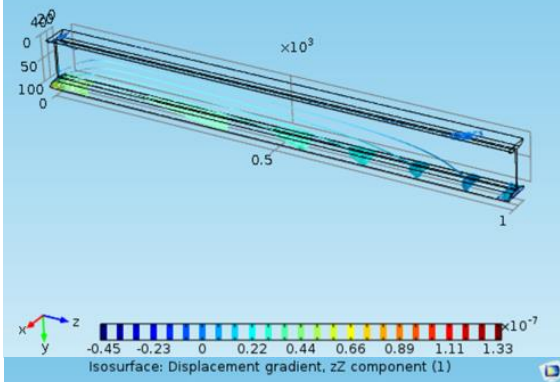

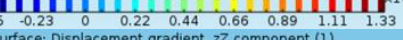

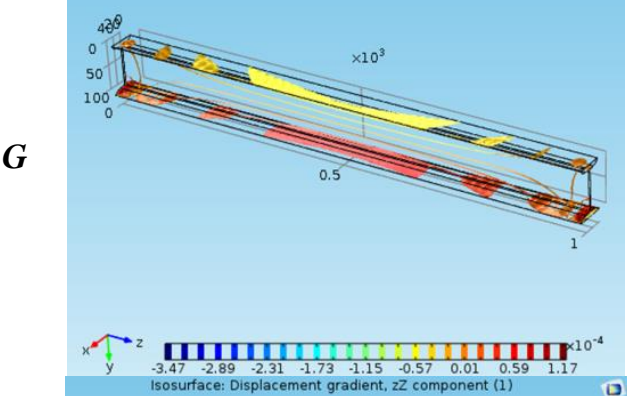

I

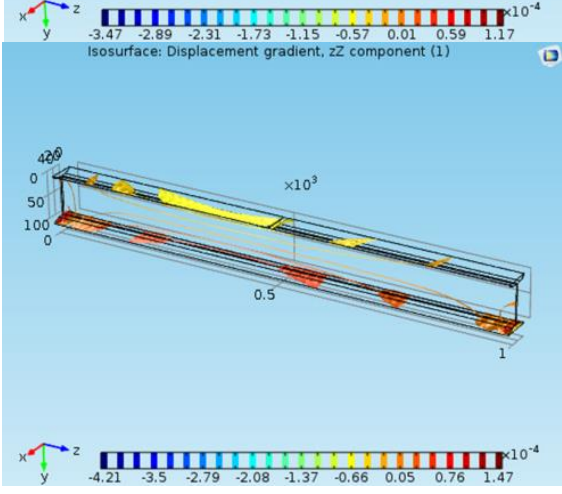

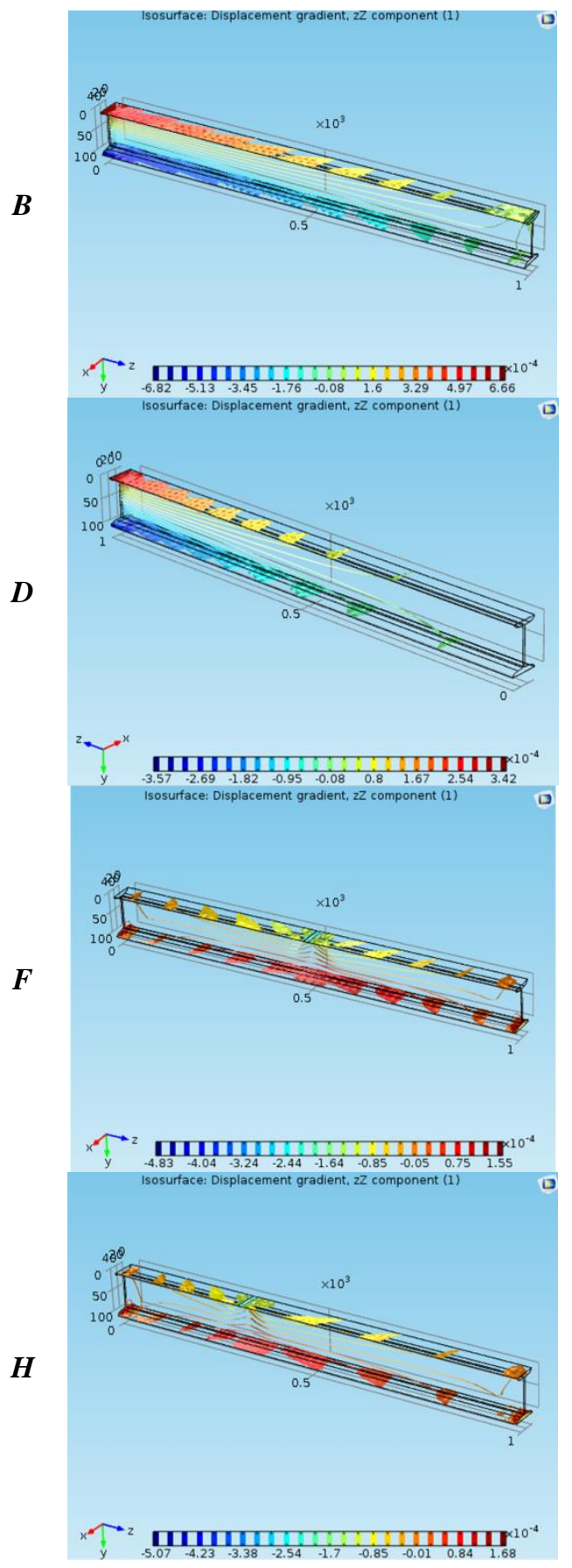

Figure 9 - Displacement gradient, $Z Z$ component: $A$ - the first scheme; $B$ - the second scheme; $C$ - the third scheme; $D$ - the fourth scheme; $E$ - the fifth scheme; $F$ - the sixth scheme; $G$ - the seventh scheme; $H$ - the eighth scheme; $I$ - the ninth scheme. 


\begin{tabular}{|c|c|c|c|c|c|c|}
\hline \multirow{4}{*}{ Impact Factor: } & ISRA (India) & $=3.117$ & SIS (USA) & $=0.912$ & ICV (Poland) & $=6.630$ \\
\hline & ISI (Dubai, UAE & $=0.829$ & РИНЦ (Russia & $=0.156$ & PIF (India) & $=1.940$ \\
\hline & GIF (Australia) & $=0.564$ & ESJI (KZ) & $=8.716$ & IBI (India) & $=4.260$ \\
\hline & JIF & $=1.500$ & SJIF (Morocco & $=5.667$ & OAJI (USA) & $=0.350$ \\
\hline
\end{tabular}

The value and the direction of the layers displacement of the I-beam material are different along the coordinate axes. The range of variation of displacement gradient is minimum along the $X$-axis (the beam width); the ranges of variation of displacement gradient are maximum along the axes $Y$ and $Z$ (the height and the length of the beam). The uniform distribution of displacement gradient of material was determined along the $Z$-axis.

\section{Conclusion}

The type of load affects the direction and intensity of deformation of the material layers of the I-beam. Distributed load leads to increasing of intensity of the layers displacement of material, and concentrated load leads to increasing of the value of the deformation coefficient of the I-beam material. The I-beam width changes in the less degree.

\section{References:}

1. Chemezov, D., Osipov, T., \& Pesenko, A. (2016). A static calculation of an I-beam. ISJ Theoretical \& Applied Science, 11 (43), 49-52.

2. Liao, S. J. (2009). Series Solution of Large Deformation of a Beam with Arbitrary Variable Cross Section under an Axial Load. Anziam Journal the Australian \& New Zealand Industrial \& Applied Mathematics Journal, 51, $10-33$.

3. Veldman, S. L., \& Bergsma, O. K. (2006). Analysis of Inflated Conical Cantilever Beams in Bending. AIAA Journal, 44, 1345-1349.

4. Cowper, G. R. (1967). The Shear Coefficient in Timoshenko's Beam Theory. Journal of Applied Mechanics, 33, 335-340.

5. Belov, V., \& Goryachevskij, O. (2017). About optimal geometric parameters of a developed Ibeam with a perforated web. MATEC Web Conf., Volume 117, 1-8.

6. Manakova, N. A., \& Vasiuchkova, K. V. (2017). Numerical investigation for the start control and final observation problem in model of an I-beam deformation. J. Comp. Eng. Math., 4:2, 26-40.

7. Van, A. L., \& Wielgosz, C. (2005). Bending and Buckling of Inflatable Beams: Some New Theoretical Results. Thin-Walled Structures, 43, 1166-1187.

8. Chemezov, D., et al. (2019). Bendings of cantilever and doubly supported steel I-beams. ISJ Theoretical \& Applied Science, 01 (69), 261267.

9. Chemezov, D., et al. (2019). Isosurfaces of mechanical stresses in cantilever and doubly supported steel I-beams subject to bending. ISJ Theoretical \& Applied Science, 02 (70), 301339.

10. Chemezov, D., et al. (2019). Deformations isosurfaces of cantilever and doubly supported steel I-beams at bending. ISJ Theoretical \& Applied Science, 03 (71), 501-513. 